\title{
The Margin of Appreciation in the ECtHR's Case Law
}

\author{
A European Version of the Levels of Scrutiny Doctrine?
}

Koen Lemmens ${ }^{*}$

\begin{abstract}
Although the American doctrine of levels of scrutiny and the European concept of margin of appreciation are regularly compared as typical instances of deferential judicial decision-making, this article argues that owing to the institutional setting in which they operate, the differences between the two are notable. It is also argued that the social consequences of the application of the two concepts may even be radically opposed.
\end{abstract}

Keywords: ECHR, judicial deference, levels of scrutiny, margin of appreciation, U.S. federalism.

\section{A Introduction}

Since fundamental rights and human rights are often understood as countermajoritarian devices, human rights adjudication has, by its nature, a political dimension. What judges will be asked to do is, in fact, to review legislation against either constitutionally protected freedoms or human rights as protected in international human rights treaties. This boils down to balancing fundamental rights against other fundamental rights or, even more frequently, against state interests. ${ }^{1}$ Judges may, in such circumstances, be reluctant to push their analysis too far, out of respect for the separation of powers. Deferential adjudication is a means of respecting separation of powers and shying away from all too political judicial decision-making. However, in federal states and in international human

* Associate professor of Public Law at KU Leuven (Belgium) and press law VU Brussels (Belgium). The author thanks Toon Agten for his comments and Camille Van Peteghem for her assistance during research. The usual disclaimer applies. This volume (The EU Bill of Rights' Diagonal Application to Member States. Ed. Csongor István Nagy) was published as part of the research project of the HAS-Szeged Federal Markets 'Momentum' Research Group.

1 A. Ostrovsky, 'What's So Funny About Peace, Love and Understanding? How the Margin of Appreciation Doctrine Preserves Core Human Rights within Cultural Diversity and Legitimises International Human Rights Tribunals', Hanse Law Review, Vol. 1, 2015, 2015, p. 60. 
rights systems, there is a second reason why deferential adjudications can be applied: accommodation of '(cultural) diversity'. ${ }^{2}$

In the U.S. legal system, the doctrine of various levels of scrutiny has been developed. Within the mechanism of the European Convention of Human Rights, the concept of margin of appreciation has been created. In the literature, both the levels of scrutiny doctrine and the margin of appreciation are often compared. ${ }^{3}$ Each of them is seen as an instance of deferential judicial decision-making. However, this article argues that although similarities exist, there are important differences as well. The margin of appreciation is indeed used by the ECtHR in much more distinct situations than the U.S. Supreme Court uses the level of scrutiny cases. I will explain that this difference is due to the specific position of the ECtHR as an international human rights court.

The literature of both the levels of scrutiny and margin of appreciation is extensive. Moreover, many authors have already compared levels of scrutiny to the way the ECtHR deals with cases brought before it. Strikingly enough, two kinds of comparison appear. On the one hand, some authors link the levels of scrutiny with the concept of proportionality. An illustrative example here is offered by A. Sweet Stone and J. Mathews. ${ }^{4}$ They hold that "proportionality balancing is an analytical procedure akin to 'strict scrutiny' in the United States." However, I am not fully convinced of the appropriateness of the comparison, as I will explain in this contribution.

On the other hand, comparisons are drawn between the 'levels of scrutiny' and 'the margin of appreciation'. ${ }^{6}$ In this article, I focus on the second cluster of comparisons, since I believe they correspond better to the underlying analytical rationale, i.e. the operation of deferential judicial decision-making. I subscribe to Mattias Kumm's observation that the incremental use of the human rights (or constitutional rights) vocabulary to frame legal problems has considerably narrowed the field for political decision-making. Kumm refers in this respect to the

2 In the context of the European system, Buanamano enumerates the leading justifications of the margin of appreciation: 'democratic legitimation' and 'lack of European consensus'. R. Buanamano, 'The Hermeuneutics of Deference in Strasbourg Jurisprudence: Normative Principles and Procedural Rationality', European Journal of Human Rights, No. 4, 2017, p. 323-327.

3 D. Donoho, 'Autonomy, Self-Governance and the Margin of Appreciation: Developing a Jurisprudence of Diversity within Universal Human Rights', Emory International Law Review, Vol. 15, 2001, p. 398, J. Westerfield, 'Behind the Veil: An American Legal Perspective on the European Headscarf Debate', American Journal of Comparative Law, Vol. 54, 2006, p. 673. More implicitly: J. Kratochvíl, 'The Inflation of the Margin of Appreciation by the European Court of Human Rights', Netherlands Quarterly of Human Rights, Vol. 29, 2011, p. 353.

4 See also P. Yowell, 'Proportionality in United States Constitutional Law', in L. Lazarus, C. McCrudden \& N. Bowles (Eds.), Reasoning Rights: Comparative Judicial Engagement, London, Hart Publishing, 2014, p. 87-114.

5 A. Stone Sweet \& J. Mathews, 'Proportionality Balancing and Global Constitutionalism', 2008, p. 1, available at: https://papers.ssrn.com/sol3/papers.cfm?abstract_id=1569344.

6 D. Beatty, 'Law and Politics', American Journal of Comparative Law, Vol. 44, 1996, p. 134-135. (Explicitly holds that 'margin of appreciation' and levels of scrutiny are about deference to 'elected branches of government'). 
problem of 'human rights inflation' as an instance of 'Juristocracy'. ${ }^{7}$ Then he goes on:

The perennial issue here is that of the appropriate degree of deference: What level of deference, "standard of review", what "margin of appreciation" should a human rights judiciary concede to national political institutions and the democratic process when it applies the proportionality test and assesses the reasons put forward by the parties? ${ }^{8}$

If one accepts this perspective, it becomes clear that the margin of appreciation and the levels of scrutiny are, or should conceptually be, "prior steps' rights adjudication. In a way, they constitute a Vorfrage: first, courts have to decide how intensive their review - if any at all - will have to be and, consequently, they can proceed to the review as such. ${ }^{10}$ Applying proportionality, as I understand it, would then be a matter of the review as such. Admittedly, this is an idealistic comment that does not necessarily correspond to what courts are, in fact, doing.

In this short contribution, I begin by closely examining the two fundamental concepts (Section B). Then, under Section C, I briefly explain why the levels of scrutiny doctrine and the margin of appreciation, notwithstanding evident commonalities, differ considerably.

\section{B Having a Closer Look at the Dyad}

\section{The Levels of Scrutiny}

The 'levels of scrutiny' is a well-known and much discussed doctrine in American constitutional law scholarship. ${ }^{11}$ Its origins date back to the seminal U.S. Supreme Court's case Carolene Products Co. ${ }^{12}$ In this case, the Supreme Court was asked to review legislation that prohibited the shipment of 'filled milk' in interstate commerce. Obviously, the aim of the Filled Milk Act was to protect the consumer. Yet the appellee argued that the Act infringed the Fifth Amendment (more precisely, due process). The Supreme Court, however, dismissed the claim, holding that the Act and its prohibition had a 'rational basis'.

In stating this, the Supreme Court created the first tier of what was going to be a three-tiered system of scrutiny. The basic level of scrutiny is indeed the

7 M. Kumm, 'Is the Structure of Human Rights Practice Defensible? Three Puzzles and Their Resolution', in V. Jackson \& M. Tushnet (Eds.), Proportionality. New Frontiers, New Challenges. Cambridge, Cambridge University Press, 2017, p. 68.

8 Kumm, 2017, p. 68-69.

9 M. Saul, 'Structuring evaluation of parliamentary processes by the European Court of Human Rights', The International Journal of Human Rights, Vol. 20, 2016, p. 1078.

10 Ibid., with reference to: J. Gerards \& H. Senden, 'The Structure of Fundamental Rights and the European Court of Human Rights', International Journal of Constitutional Law, Vol. 7, 2009, p. 651.

11 This analysis relies essentially on Yowell, 2014, p. 94 et seq.

12 United States v. Carolene Products Co, 304 U.S. 144 (1938). 
'rational basis' test. When the Court applies this test, it will stick to a minimum level of scrutiny, focusing on the question whether the legislation under review respects the (minimal) standard of rationality. What is scrutinized is whether there is a rational link between a rule or measure and the legitimate aims pursued. ${ }^{13}$ The concept of 'reasonable justification' brings both conditions quite accurately together. ${ }^{14}$ Specifically in economic affairs (including trade) and social welfare (including workplace) this test is applied. ${ }^{15}$

However, Carolene Products entered into history because of Footnote 4.

There may be narrower scope for operation of the presumption of constitutionality when legislation appears on its face to be within a specific prohibition of the Constitution, such as those of the first ten amendments, which are deemed equally specific when held to be embraced within the Fourteenth." (...)

$[\mathrm{P}]$ rejudice against discrete and insular minorities may be a special condition, which tends seriously to curtail the operation of those political processes ordinarily to be relied upon to protect minorities, and which may call for a correspondingly more searching judicial inquiry. (...)

In other words, the Supreme Court indicated that there can be circumstances in which a stricter scrutiny must be applied. The judges did not, however, explain how in economic matters the judicial deference had to be conceived; neither did they explain how intense the review in more 'sensitive' cases had to be. ${ }^{16}$

The case law of the Supreme Court then gradually developed, giving more indications on how the levels of scrutiny system should be understood. At present, and notwithstanding criticism on the framework, three levels of scrutiny are usually underscored. It should be noted, though, that some authors go further and discern more levels: Kelso defends the idea that there are up to 7 levels of scrutiny. ${ }^{17}$

As indicated, the first, basic level is the rational basis test. Applied in economic and social welfare cases, and in "most regulation not affecting an enumerated or fundamental right," 18 the test gives great deference to the public authorities. In fact, as long as a law has a reasonable justification, it will not be held unconstitutional. There is, in other words, a strong 'presumption of validity', ${ }^{19}$

13 A. Belzer, 'Putting the Review Back in Rational Basis Review', Western State University Law Review, Vol. 41, 2014, p. 344; Yowell, 2014, p. 95.

14 Belzer, 2014, p. 340.

15 J. Nowak \& R. Rotunda, Constitutional Law (Hornbook Series), Saint Paul, West, 2010, p. 483.

16 Ibid.

17 R. Kelso, 'Standards of Review under the Equal Protection Clause and Related Constitutional Doctrines Protecting Individual Rights: The Base Plus Six Model and Modern Supreme Court Practice', University of Pennsylvania Journal of Constitutional Law, Vol. 4, 2002, p. 225-259.

18 Yowel, 2014, p. 95.

19 Nowak \& Rotunda, 2010, p. 487. 
even reinforced by the fact that it is up to the applicants to prove that the law they challenge has no rational basis. ${ }^{20}$

However, things are more complicated whenever fundamental constitutional rights are at stake. Should governmental actions infringe on fundamental constitutional rights, the Supreme Court will follow a strict scrutiny analysis. Under due process, it will look for a 'compelling state interest' that has to be 'narrowly tailored'. ${ }^{21}$ If interferences with fundamental constitutional rights are not 'narrowly tailored' and if they do not respond to a compelling state interest, they will fail to pass the test. In equal protection cases, a similar approach will be taken, albeit that the legal questions will be focused on two kinds of situations. ${ }^{22}$ First, strict scrutiny will be applied whenever legislation or governmental action makes a distinction between persons based on a suspect status (i.e. a criterion that triggers the specific attention of the Court since it would be prone to arbitrary use). ${ }^{23}$ Suspect qualifications are: alienage, ${ }^{24}$ race $^{25}$ and national origin. ${ }^{26}$ Second, whenever policies burden the enjoyment of fundamental rights, the strict scrutiny test will be applied. ${ }^{27}$ Laws will be a burden to fundamental rights whenever they have an impact on the fundamental guarantees of the Bill of Rights and on some other, limited category of rights. ${ }^{28}$

Finally, in between 'strict scrutiny' and 'rational basis', there is a third level of scrutiny. This review is used whenever, in equality protection cases, distinctions (i.e. qualifications) are made, based on 'quasi-suspect' criteria. ${ }^{29}$ In this context 'quasi-suspect' refers to groups of people who are not politically voiceless, but who nevertheless lack 'substantial political power'. ${ }^{30}$ These groups include people classified on the basis of gender ${ }^{31}$ and illegitimacy. ${ }^{32}$ In order to pass the constitutional threshold, it must be proven that a law 'substantially' pursues an 'important state interest'. ${ }^{33}$ In some free speech cases, intermediate scrutiny is equally applied by the Court. ${ }^{34}$

Belzer, 2014, p. 340.

Yowell, 2014, p. 95; R. Rotunda \& J. Nowak, Principles of Constitutional Law (Concise Hornbooks), Saint-Paul, West, 2016, p. 427

Nowak \& Rotunda, 2010, p. 750

Ibid., p. 750. However, as Baker notes, there does not seem to be a clear criterion to determine which are suspect criteria and which are not. A. Baker, 'Proportional, Not Strict Scrutiny: Against a U.S. Suspect Classifications Model under Article 14 ECHR in the U.K.', American Journal of Comparative Law, Vol. 56, 2008, p. 878-879.

Graham v. Richardson, 403 U.S. 365 (1971).

Korematsu v. United States, 323 U.S. 214 (1944).

Yowell, 2014, p. 96.

Baker, 2008, p. 68.

Nowak \& Rotunda, 2010, p. 502.

Baker, 2008, p. 869.

https://www.law.cornell.edu/wex/equal_protection (last accessed 17 January 2018). See as well, Baker, at note 22008, p. 892.

Craig v. Boren, 429 U.S. 190 (1976).

Weber v. Aetna Casualty \& Surety Co, 406 U.S. 164 (1972).

Nowak and Rotunda, 2016, p. 428.

See Yowell, 2014, p. 96-97 for some examples. 
In his contextual analysis of what he calls the 'Footnote 4 jurisprudence', Mark Tushnet observes an interesting evolution, however. ${ }^{35}$ Indeed, the original idea seemed to be that through the mechanism of Footnote 4, a certain marge de manoeuvre was left to legislatures to adopt specific socio-economic legislation, therefore finding 'New Deal' kind of legislation in line with the Constitution. This was seen, at that time, as a progressive or liberal approach. ${ }^{36}$ However, as Tushnet notes, the exceptions where stricter scrutiny was suggested by the footnote and that the author links to the protection of African-Americans and the protection of freedom of speech in the aftermath of World War I - have gradually been used, by the end of the twentieth century, to challenge legislation in any field, since it would infringe upon personal autonomy. ${ }^{37}$ The argument is that it is not difficult, once one accepts that political democracy is a game of interest groups, to understand that what constitutes 'a discrete and insular minority' may quite well be the result of successful lobbying. Perhaps other groups are entitled to a similar protection as well. So unless one wanted to get rid of the whole idea of judicial scrutiny (thus extending the deference in social-economic questions to everything), the alternative was to diversify and include all kinds of groups suffering from similar forms of political disadvantage as the groups initially intended by the qualification 'discrete and insular minority'. ${ }^{38}$ Ultimately, Tushnet argues, personal autonomy has become the dominant constitutional lens through which legislation is analysed. ${ }^{39}$

Interestingly, the American constitutionalist analyses this evolution as libertarian values pairing with, if not overturning, traditional liberalism. ${ }^{40}$ As a result, the very idea of society as a shared, common good has vanished. ${ }^{41}$ Tushnet's point is fascinating since it highlights an evolution that can be observed in Europe as well. Authors such as Laurent Bouvet ${ }^{42}$ or Marcel Gauchet ${ }^{43}$ in France have also underlined how the traditional leftish political parties have gradually 'shifted' their focus from 'the people' ('le peuple') towards disempowered minorities. An influential leftist think tank, Terra Nova, suggested the French PS to move in that direction, since it has (definitely) lost its working class constituency. ${ }^{44}$ In recent times, debates on religious accommodation in Europe

M. Tushnet, The Constitution of the United States of America, Oxford, Hart Publishing, 2009, p. 205 et seq.

36 Ibid., p. 205.

37 Ibid., p. 207-208.

38 Ibid., p. 205.

39 Ibid., p. 211 et seq.

40 Ibid., p. 210.

41 Ibid., p. 234-235.

42 See, e.g., L. Bouvet, 'Le sens du peuple', Le débat, 2011, p. 136-143.

43 M. Gauchet, Comprendre le malheur français, Paris, Stock, 2016.

44 http://tnova.fr/rapports/gauche-quelle-majorite-electorale-pour-2012 (last accessed 17 January 2018). 
lay bare a similar tendency: the risk to focus so much on individual rights that social cohesion is completely overlooked. ${ }^{45}$

\section{The Margin of Appreciation}

Few topics in the law of the European Convention on Human Rights (ECHR) have fuelled such a living debate and consequently bolstered so much criticism as the margin of appreciation. It would be impossible to include a general overview of the vast literature in the field. In this contribution my focus is on the concept and its origins and the circumstances in which it plays a role.

\section{The Origins}

The term 'margin of appreciation' or 'margin of discretion' was already present in the debates in earlier cases, ${ }^{46}$ but the ECtHR developed it in the seminal Handyside-case. In the words of the Court - and a longer excerpt is justified:

48. The Court points out that the machinery of protection established by the Convention is subsidiary to the national systems safeguarding human rights (judgment of 23 July 1968 on the merits of the "Belgian Linguistic" case, Series A no. 6, p. 35, para. 10 in fine). The Convention leaves to each Contracting State, in the first place, the task of securing the rights and liberties it enshrines. The institutions created by it make their own contribution to this task but they become involved only through contentious proceedings and once all domestic remedies have been exhausted (...).

These observations apply, notably, to Article 10 para. 2. In particular, it is not possible to find in the domestic law of the various Contracting States a uniform European conception of morals. The view taken by their respective laws of the requirements of morals varies from time to time and from place to place, especially in our era which is characterised by a rapid and far-reaching evolution of opinions on the subject. By reason of their direct and continuous contact with the vital forces of their countries, State authorities are in principle in a better position than the international judge to give an opinion on the exact content of these requirements as well as on the "necessity" of a "restriction" or "penalty" intended to meet them. Consequently, Article 10 para. 2 leaves to the Contracting States a margin of appreciation. This margin is given both to the domestic legislator ("prescribed by law") and to the bodies, judicial amongst others, that are called upon to interpret and apply the laws in force...

On this, K. Lemmens, 'Religare, Believers and Non-Believers: But Where Is the Citizen?', in M.-C. Foblets, K. Alidadi, J.S. Nielsen \& Z. Yanasmayan (Eds.), Belief, Law and Politics: What Future for a Secular Europe. Surrey, Ashgate, 2014, p. 237-244.

46 On the first cases: Y. Arai-Takahashi, The Margin of Appreciation Doctrine and the Principle of Proportionality in the Jurisprudence of the ECHR, Antwerp, Intersentia, 2002, p. 5-7. See as well: O. Gross \& F. Ni Aolain, 'From Discretion to Scrutiny: Revisiting the Application of the Margin of Appreciation Doctrine in the Context of Article 15 of the European Convention on Human Rights', Human Rights Quarterly, Vol. 23, 2001, p. 630 et seq. 
49. Nevertheless, Article 10 para. 2 does not give the Contracting States an unlimited power of appreciation. The Court, which, with the Commission, is responsible for ensuring the observance of those States' engagements (Article 19), is empowered to give the final ruling on whether a "restriction" or "penalty" is reconcilable with freedom of expression as protected by Article 10. The domestic margin of appreciation thus goes hand in hand with a European supervision. Such supervision concerns both the aim of the measure challenged and its "necessity"; it covers not only the basic legislation but also the decision applying it, even one given by an independent court. ${ }^{47}$

Since 1976, the margin of appreciation has become an essential part of the Court's case law. This did not, however, go unnoticed. The literature has been paying a lot of - critical - attention to the margin of appreciation. But even judges proved to be very critical. Most famous are Judge De Meyer's words:

I believe that it is high time for the Court to banish that concept from its reasoning. It has already delayed too long in abandoning this hackneyed phrase and recanting the relativism it implies. ${ }^{48}$

De Meyer believed indeed that the margin of appreciation was only a smokescreen behind which "the States may do anything the Court does not consider incompatible with human rights." 49

However, instead of disappearing from the stage, the margin of appreciation made a spectacular reappearance in recent times. In the last decade, the Court was severely criticized, as is commonly known, for its dynamic interpretation of the Convention, often to the detriment of local diversity. ${ }^{50}$ One way for the Court to tackle this criticism was to stress its 'subsidiary role' in the mechanism of human rights protection, thereby underlining the fact that national authorities have a primary duty to protect human rights under the Convention. This gentle way of taking into consideration the criticism of the contenders has perhaps been best expressed in the Taxquet case on the Belgian lay jury system, where the Court clearly indicated:

The jury exists in a variety of forms in different States, reflecting each State's history, tradition and legal culture; variations may concern the number of jurors, the qualifications they require, the way in which they are appointed and whether or not any forms of appeal lie against their decisions (...). This is just one example among others of the variety of legal systems existing in Europe, and it is not the Court's task to standardise them. A State's choice of a particular criminal-justice system is in principle outside the scope of the

50 For an overview of the discussion, see P. Popelier, S. Lambrecht \& K. Lemmens (Eds.), Criticism of the European Court of Human Rights. Shifting the Convention System: Counter-Dynamics at the National and EU Level, Cambridge, Intersentia, 2016. 
supervision carried out by the Court at European level, provided that the system chosen does not contravene the principles set forth in the Convention $(\ldots) .^{51}$

Politicians, debating on the reform and the future of the Court, have realized the potential of the margin of appreciation. They highlighted that the margin of appreciation could serve as a very useful tool to appease the tensions between the Court and the States. As a result, Protocol no. 15, which is open for ratification, aims, among other things, to incorporate the margin of appreciation in the Preamble of the Convention. ${ }^{52}$ The proposed recital reads:

Affirming that the High Contracting Parties, in accordance with the principle of subsidiarity, have the primary responsibility to secure the rights and freedoms defined in this Convention and the Protocols thereto, and that in doing so they enjoy a margin of appreciation, subject to the supervisory jurisdiction of the European Court of Human Rights established by this Convention.

One could wonder what the extra value is of the 'textual consecration' of a judgemade creation. The answer has both a symbolic and a more legal dimension. Symbolically, the 'conventionalization' of the margin of appreciation confirms its central role as a diversity accommodating device. Legally, notwithstanding the fact that the margin is going to be only part of the Preamble and not of the Convention, the message sent to the Court is clear. The Preamble serves as an interpretative tool (see Art. 31 Vienna Convention of the Law of Treaties), and by including the margin of appreciation, it imposes on the Court the duty to interpret the Convention in the light of the margin of appreciation. In other words, however unlikely this may seem, at the time of Judge De Meyer, the Court could have done away with the margin of appreciation. When it is integrated in the Preamble, that option will no longer be available.

\section{The Concept and Its Application}

In an extensive overview of the Court's case law involving the use of the margin of appreciation, Jan Kratochvíl draws a hard conclusion. He saw 'much inconsistency and adhockery', an 'eclectic case-by-case analysis' of the doctrine, with no specific underlying theory. ${ }^{53}$ Within the limited scope of this contribution, it will not be my aim to give a comprehensive overview of all the situations in which the Court uses the margin of appreciation. For the purpose of this article, a general presentation of the margin of appreciation can suffice.

Two questions are important here. The first relates to domains where the ECtHR uses the margin of appreciation. The second pertains to the width of the margin.

ECtHR (GC), Taxquet v. Belgium, 16 November 2010, § 83.

www.echr.coe.int/Documents/Protocol_15_ENG.pdf (last accessed 17 January 2018).

Kratochvíl, 2011, p. 351. 
a) Areas in Which the Margin of Appreciation Is Applied

As an expert on the conceptual design of the ECHR, Letsas developed the idea of the existence of two distinct forms of margin of appreciation: a substantive one and a structural one. ${ }^{54}$ The former relates to the balancing of the protected rights, that is the 'relationship between individual freedoms and collective goals', whereas the latter is concerned with the review process by the Strasbourg Court as such. By distinguishing both conceptions, Letsas enables us to understand that 'deference' under the Strasbourg system can mean (at least) two different things. It can refer to classic issues of horizontal separation of powers (the deference to

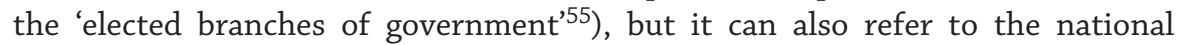
authorities in the framework of a discussion on vertical separation of powers.

These two dimensions appear as well, albeit perhaps in a slightly altered form, in the work of other scholars. In a recent contribution, Arnardóttir underscores a similar dyad. The author distinguishes a 'systemic' component concerning the relation between the Strasbourg Court and the domestic authorities and a 'normative dimension' relating to the conventionally protected rights per se. In the latter case, the focus is on the strength and the boundaries of rights and the way the Court deals with these questions. ${ }^{56}$

Obviously, both dimensions can and will overlap. It will not always be possible to ascribe a case in which the Court applies the margin of appreciation to either dimension. Often both dimensions are intertwined. ${ }^{57}$ This is because the margin of appreciation's rationale, as expressed in Handyside, is the 'better placement ${ }^{58}$ idea. It goes without saying that this justification operates in both ways: the Court may find that national authorities are better placed than an international Court as it may find that 'elected bodies of government' (Beatty) are more suited to decide than judges. Both considerations are not mutually exclusive.

Browsing through the case law on the margin of appreciation, we can distinguish some prominent categories of situations in which the Court typically refers to the margin. Once again, this classification is not comprehensive: the 'adhockery' (Kratochvíl) at stake explains why a vast 'rest category' would be appropriate. ${ }^{59}$ Combining approaches of Kratochvíl ${ }^{60}$ and $S m e t^{61}$, I focus on three important categories: discussions on the law, discussions on the facts and concerns about positive obligations.

G. Letsas, A Theory of Interpretation of the European Convention on Human Rights, Oxford, Oxford University Press, 2007, p. 80-81.

55 Beatty, 1996, p. 132.

56 O. Arnardóttir, 'Rethinking the Two Margins of Appreciation', European Constitutional Law Review, Vol. 12, 2016, p. 41-43. On this see Buanamano, 2017, p. 323-324.

57 Buanamano, 2017, p. 323.

58 I take the term from Buanamano, 2017, p. 324.

59 On this rest category, see Kratochvíl, 2011, p. 334 et seq.

60 Kratochvíl, 2011, p. 329-353.

61 S. Smet, "When Human Rights Clash in "the Age of Subsidiarity". What Role for the Margin of Appreciation?', in P. Agha (Ed.), Human Rights Between Law and Politics. The Margin of Appreciation in Post-National, Oxford, Hart Publishing, 2017, p. 59 et seq. 
Discussions on the (Non)-Existence of a Specific Law

A first category of hypothesis in which the margin of appreciation plays a key role concerns cases where the very existence - or absence - of a legal prescript is called into question. An emblematic case in this respect is S.A.S v. France on concealing the face in public (the so-called burqa ban). ${ }^{62}$ The question, in that case, was whether the ban on concealing the face in public places, which obviously has (also) an impact on some Islamic women wearing niqabs or burka's, would constitute a violation of Article 9 ECHR (protecting freedom of religion and consciousness).

The Court eventually did not find a violation of the Convention. A key factor in that finding was the 'margin of appreciation'. The Court recalled indeed that States have a wide margin of appreciation when it comes to establishing rules on religion/state relations. ${ }^{63}$ More precisely, and in more general terms, the Court observed:

that in matters of general policy, on which opinions within a democratic society may reasonably differ widely, the role of the domestic policy-maker should be given special weight. ${ }^{64}$

What is at stake in cases of this kind is, in other words, both the horizontal separation of powers and the vertical one. Indeed, when the Court refers to 'policymaker' it underlines the function of the 'elected branches of government'. But where it stresses 'domestic', it is clear that the Court leaves room for 'local' diversity.

It may not come as a surprise that whenever legal norms concern issues that are related to public morals, ethics, religion and traditions, the Court will refer to the margin of appreciation. Hence, in cases such as S.H. and other v. Austria ${ }^{65}$ (on medically assisted procreation) or Garib v. the Netherlands ${ }^{66}$ (on restrictions on the right to choose one's residence) the discussion on the margin of appreciation played an important role. The Court will pay special attention to the quality of the legislative process, implying that it will evaluate whether the legislature has struck a fair balance, taking into account all interests at stake. ${ }^{67}$ Not so much the use, but the width of the margin will be the object of the discussion.

In these cases, the Court's functioning could be compared to that of a Constitutional Court. The review is indeed rather ${ }^{68}$ abstract in its nature. What the Court does is set a 'conventional floor'. States must meet that minimum level of

68 See ECtHR, J.M. and Others v. Austria, 1 June 2017, § 117, where the Court points out that its task is not to do an abstract review of the legislation but to link its review to the 'issues' raised before it. 
human rights protection, but once this threshold is reached, the Court will refrain from intervening. ${ }^{69}$

Discussions about the Relation between Legal Norms and Facts

A second category of cases pertains to the discussion of the applications of the norm to the facts. What is at stake is not so much the very existence (or absence) of the legal rule but rather the way the rule is connected to the facts of the case. Kratochvíl calls this the cases of 'norm application'. ${ }^{70}$

Typical of cases of this kind is that the norms as such are not contested, but their application (to the facts) is. It is not surprising that in this kind of cases, the Court does give leeway to the domestic authorities since the Court is not a fourth instance. Fact-finding and applying the law to the facts is essentially a task for the domestic authorities. The role of the Court in this respect is to assess, from a distance, whether the application of the law fits within the Conventional framework.

In doing this, the Court's action comes close to what a supreme court of the French Cour de cassation type or Conseil d'Etat would do. The term margin of appreciation indeed derives from French administrative law, where, since the 1960s, it has been accepted that the administrative authorities enjoy a wide discretionary power, which will be scrutinized by the administrative judges and sanctioned in case of an 'erreur manifeste d'appréciation'. ${ }^{71}$ However, it should be borne in mind, as Arai-Takahashi notes, that the concept is known in the administrative law of most civil law jurisdiction, such as the German concepts of Beurteilungsspielraum and Ermessensspielraum. ${ }^{72}$

As indicated earlier, it will not always be easy to distinguish the Court's 'supreme court's approach' and its 'constitutional function'. This is in part due to the standing of victims in Strasbourg. Save exceptions, applicants will have to show that they suffered a substantial disadvantage. This excludes as a rule potential victims. Although, in exceptional circumstances, also potential victims can successfully file a complaint. In that case, the debate will indeed focus on the mere existence of the norm. In other cases, the application of the law will always play, albeit perhaps very timidly, a role. However, this does not mean that we cannot distinguish cases where the discussion concerns more the existence of a norm from those where the discussion pertains to the application. Yet, the distinction is not a watershed.

A recent example illustrates how both dimensions can be very much intertwined. Previously, I indicated how the French 'burqa ban' gave rise to the S.A.S.

69 For the idea of a 'Conventional floor', see F. Fabbrini, Fundamental Rights in Europe. Challenges and Transformations in Comparative Perspective, Oxford, Oxford University Press, 2014, p. 38-39.

70 Kratochvíl, 2011, p. 329.

71 P. Serrand, Droit administratif. Tome 2. Les obligations administratives, Paris, Presses Universitaires de France, 2015, p. 117 ; P.-L. Frier \& J. Petit, Droit administratif, Paris, LGDJ, 2013, p. 547; Arai-Takahashi, 2002, p. 2.

72 Arai-Takahashi, 2002, p. 2-3. On Beurteilungsspielraum and Ermessensspielraum, see J. Ipsen, Allgemeines Verwaltungsrecht, München, Verlag Franz Vahlen, 2017, p. 122-137; D. Ehlers, 'Verwaltungsgerichtliche Anfechtungsklage', in D. Ehklers \& F. Schoch (Eds.), Rechtsschutz im Öffentlichen Recht, Berlin, De Gruyter Recht, 2009, p. 631-364. 
judgment, where the Court had to assess the law against the Convention. In Belgium, a similar ban was passed, and, unsurprisingly, this led to a case in Strasbourg. ${ }^{73}$ It was expected that the Court would uphold its earlier findings, which it eventually did. Nevertheless, there is a difference between the two cases. The concurring opinion of Judge Spano (joined by Judge Karakaş) in the Belcacemi and Oussar case against Belgium in this respect is essential. Both judges recognize that the cases concerning Belgium implied an 'abstract scrutiny' of the legislation. However, they indicate as well that, in their view, there would be a problem in terms of the proportionality of the sanctions had an applicant complained of the sanctions imposed on him or her. ${ }^{74} \mathrm{Had}$ there been sanctions, the question would definitely be whether, applied to the facts at hand, they would have fallen within the margin of appreciation of the national authorities.

\section{Concerns on Positive Obligations}

The third category of cases pertains to positive obligations. It is well known that the ECtHR has developed an important doctrine of positive obligations. Although these obligations are usually connected with second generation rights, the Court has applied them extensively to the ECHR. ${ }^{75}$ The positive duties thus imposed on States force them to undertake actions. This may include investigations (e.g. in case of police violence), legal actions (e.g. against the persons responsible for the violation) or the design of a legal framework (which can prevent, for instance, some violations of the Convention from occurring).

It follows, in other words, that States are bound to act. However, these positive obligations as created by the Court should not conflict with the very idea of the separation of powers. Thence, whenever States are under the Conventional obligation to intervene and develop a 'policy', they will enjoy some leeway. This is what is understood by the idea of 'choice of means'. The Court will grant, indeed, a margin of appreciation to allow States to design a policy. A similar reasoning applies to discussions on Article 46 ECHR on the execution of the Strasbourg Court's judgments. In order to respect the separation of powers, the Court will leave States a margin to choose the way they deem most appropriate to comply with their obligations under the Convention.

However, pushing the argument a little further, it may become clear that whenever positive obligations are accepted, clashes of rights may become frequent. The obligations to protect one right may indeed collide with the obligations under another conventional right. States will have to strike, in this respect, a fair balance between the conflicting obligations. This is typically so in cases where, e.g., protection of privacy needs to be balanced against the protection of

In fact, two judgments were delivered. One case concerned a local, municipal ban, the other the federal ban. The outcome in both cases, handed down on the same day, is obviously similar, and so are the concurring opinions of judges Spano and Karakaş. ECtHR, Dakir v. Belgium, 11 July 2017 (municipal ban) and ECtHR, Belcacemi and Oussar v. Belgium, 11 July 2017 (federal ban).

75 In his book on the Convention, C. Grabenwarter was able to refer to positive obligations in the context of most of the rights protected by the Convention. C. Grabenwarter, European Convention on Human Rights, Munich/Oxford/Baden-Baden, Beck/Hart/Nomos, 2014. 
freedom of expression. States may find themselves in such cases in a very difficult position. Protecting one right may indeed bring about the underprotection of another.

The Court has recognized that in these fields of 'clashes of rights' (Smet) the margin of appreciation has a role to play. ${ }^{76}$ This follows from cases such as Evans $^{77}$, Frette ${ }^{78}$ and Odièvre ${ }^{79}$, which Smet considers to be the landmark cases in the field. ${ }^{80}$ Smet is clearly right, however, when he indicates that there is no consistent theory on the side of the Court on the use of the margin in these situations. ${ }^{81} \mathrm{He}$ quite rightly argues that the Court's approach fails to explain the reasons why it uses the margin of appreciation in these circumstances as well as its width.

However, he argues that there is a way the Court can meaningfully apply the margin of appreciation in cases of clashing rights. This can be done by taking the 'better placed' rationale seriously. ${ }^{82}$ In this interpretation, the Court can grant domestic authorities some leeway when it comes to solving human rights clashes - for these domestic authorities may have more means to circumvent the clash, they can understand better which right should prevail in the given context - but, Smet insists, the mere fact that a margin is conceded should not be conflated with its breadth. ${ }^{83}$ In other words, the author does not accept the view that granting a margin of appreciation therefore automatically implies that a very loose control is exercised. He would argue that the traditional factors used by the Court to determine the width of the margin of appreciation should still be applied. In other words, the mere fact that in case of clashes of fundamental rights, the Court is using a marginal control kind of review should not mean that there cannot be different levels of scrutiny within the field of marginal review. ${ }^{84}$ The question about the breadth of the margin of appreciation is therefore fundamental.

b) Width of the Margin

A second important question concerns the width of the margin. It is indeed one thing to identify the kind of cases in which the Court usually grants States a margin of appreciation, and another thing to decide how wide this margin will be. This part can therefore be particularly usefully compared to the levels of scrutiny in the United States. However, once again, it should be borne in mind that the Court, lacking a clear systematic approach of the margin of appreciation, often does not say anything on the width of the margin explicitly. ${ }^{85}$ The most basic

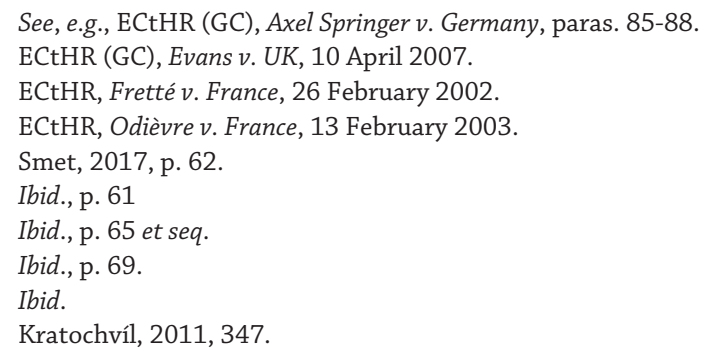


divide that can be made is, therefore, the distinction between a wide and a narrow margin of appreciation.

Traditionally, some criteria have been put forward to determine the scope of the margin of appreciation. Among the factors that would lead to a rather wide margin of appreciation we find the 'European consensus'. This means that whenever there is (legal, moral, cultural...) divergence in the European States, the ECtHR will recognize that European States dispose of a wide margin of appreciation to regulate a behaviour. ${ }^{86}$ It does not follow, however, that when there is a consensus on a given topic in European States, there will not be place for a margin of appreciation. This is fairly well illustrated by the case A. B. and C. v. Ireland on abortion. The Court explicitly found:

even if it appears from the national laws referred to that most Contracting Parties may in their legislation have resolved those conflicting rights and interests in favour of greater legal access to abortion, this consensus cannot be a decisive factor in the Court's examination of whether the impugned prohibition on abortion in Ireland for health and well-being reasons struck a fair balance between the conflicting rights and interests, notwithstanding an evolutive interpretation of the Convention (...). ${ }^{87}$

Next, as the A, B and C cases also illustrates, the margin of appreciation may be wide when it comes to culturally, morally or religiously sensitive issues. In recent times, relations between religion and law (state) have led to heated debates in many European countries and to difficult, controversial judgments by the Strasbourg Court. But whether the matter at stake was the display of crucifixes in Italian public schools ${ }^{88}$ or restrictions on concealing the face in the public sphere (the so-called burqa ban), ${ }^{89}$ the Strasbourg Court left a rather wide margin of appreciation. A wide margin of appreciation is equally granted, to Smet's dislike, in cases where private and public interests compete or Convention rights conflict. ${ }^{90}$

Other factors may lead to a restriction of the margin of appreciation. A strong European consensus in non-sensitive issues will rather lead to a restricted margin of appreciation. This can be illustrated, for instance, by the Court's conception of freedom of the press. Given the "essential role of the press in ensuring the proper functioning of political democracy (...). The margin of appreciation to be accorded to the State in the present context is, in principle, a narrow one." 91 From the Perspective of the International and Constitutional Functions of the European Court of Human Rights', p. 11. www.reei.org/index.php/revista/num29/.../Nota_MENA_FJ.pdf (last accessed 18 January 2018).

87 ECtHR (GC), A.B. and C. v. Ireland, 16 December 2010, § 237.

88 ECtHR (GC), Lautsi and Others v. Italy, 18 March 2011.

89 See ECtHR (GC), S.A.S. v. France, 1 July 2014; ECtHR, Dakir v. Belgium, 11 July 2017 and ECtHR, Belcacemi and Oussar v. Belgium, 11 July 2017.

90 ECtHR (GC), Paradiso and Campanelli v. Italy, 24 January 2017, § 182.

91 ECtHR, Redaktsiya Gazety Zemlyaki v. Russia, 21 November 2017, § 39 and 35. See as well: ECtHR (GC), Animal Defenders International v. UK, 22 April 2013, § 102. 
The margin will be narrow as well whenever the restricted right at stake concerns a "particularly important facet of an individual's existence or identity." 92 This is typically so in cases on private life issues, such as same-sex marriages, transgenderism and adoption. However, these considerations can be overruled by the factors previously referred to as being elements in favour of a wide margin.

\section{Explaining Similarities and Differences}

From a very general point of view, it is not hard to see that both 'levels of scrutiny' and 'margin of appreciation' are concepts that aim at restricting the potential impact of the judiciary on decisions taken by lawmakers. They confirm, in other words, leeway to political decision-making. In this respect, they are perfectly comparable.

Yet apart from these very general observations concerning the commonalities of both concepts, the differences seem to be much more revealing. First, it is striking that the U.S. levels of scrutiny doctrine appear to be much more conceptualized than the European margin of appreciation doctrine. Compared with the European approach, which Janneke Gerards called 'a sliding scale', 93 the U.S. levels of scrutiny doctrine is much stricter, generally leading to more predictable outcomes. Under the U.S. three-tier test, there seems to be indeed a much stricter categorical use of the levels of scrutiny than is the case in the ECtHR's case law. This 'rigidity' is expressed in two ways. On the one hand, as Gerards ${ }^{94}$ has shown, the choice of a level almost immediately determines the outcome of the case. The rational basis test will hardly lead to a violation of the Constitution, whereas strict scrutiny will much more often than not result in finding one. ${ }^{95}$ On the other, as Gerards ${ }^{96}$ equally pointed out (albeit in the context of equal treatment), only a 'limited number' of fields are subject to the intermediate or strict scrutiny. This implies that a great deal of the legislation will be subject only to the rational basis test.

Second, there is an important difference as to the 'default' position. The American standards of review imply that the default position is the less strict test. When there are weighty reasons, however, stricter or even, exceptionally, strict review will be applied. The European test, precisely because of the adhockery of the case law, cannot be described in these terms of a 'default position'. The ECtHR is simply too imprecise in the use of margin of appreciation, sometimes qualified by the judges as a 'wide' margin of appreciation or a 'narrow' one, but sometimes as 'a certain' 97 margin of appreciation.

92 ECtHR, Orlandi and others v. Italy, 14 December 2017, § 203.

93 J. Gerards, 'Intensity 'Intensity of Judicial Review in Equal Treatment Cases', Netherlands International Law Review, Vol. 51, 2004, p. 152.

94 Gerards, 2004, p. 151.

95 Gerards, 2004, p. 149. However, and in spite of a popular quote ("Strict scrutiny is strict in theory, fatal in fact", going back to the work of Gerald Gunther), empirical research indicates that $30 \%$ of the cases survived the test). See Yowell, 2014, p. 96, 98.

96 Gerards, 2004, p. 150.

97 On this, see Kratochvíl, 2011, p. 340-342. 
The question then is why this would be so. The answers to that may seem obvious but are worth recalling. ${ }^{98}$ The Supreme Court of the United States is a national court, whereas the ECtHR is an international court. In terms of judicial deference, this means that the debate on judicial deference concerns more the tension between the political sphere and the legal one (horizontal separation of powers), but not issues of sovereignty. Within the European system, on the contrary, this aspect is very important. Obviously, every judge may be challenged in terms of whether or not he or she is overstepping the boundaries of the judiciary, thus entering the political sphere, but few will have to question whether they are not overstepping their subsidiary role. Whereas the U.S. Supreme Court is the keystone of the U.S. judiciary, the role of the ECtHR is completely different.

The ECtHR indeed has only a subsidiary mission. It functions on the premises that the domestic authorities, therefore including the domestic courts, are the most important actors in upholding human rights. Only where those national actors fail, the Court has a role to play. So from an institutional point of view, the system is based on a dialogue rather than on a mere opposition, between domestic authorities and the Court. Whenever the Court refers to the margin of appreciation, it is not jeopardizing the Conventional system. Rather, it is giving more voice to the national authorities in the dialogue. It should be noted, however, that this kind of 'tuning' is not unrestricted, since, as the Court itself indicated, the conferral of a margin of appreciation goes hand in hand with European supervision. ${ }^{99}$

Obviously, the way the ECtHR can decide which party to the dialogue may have the 'louder voice' is closely related to the issue of legitimacy as well. In American constitutional law, the Constitution is the supreme law of the land. If this supreme law established (Art. III, Section 1) a Supreme Court, the normative legitimacy of this institution is solid. The legitimacy of the ECtHR (and the Convention as such) is, however more debated. There is a difference in terms of democratic legitimacy between domestic courts, acting upon the Constitution, and an international Court, functioning on the basis of an international treaty. The legitimacy issue is a complex one, but suffice it here to stress that one of the arguments that was recently quite often expressed in the debate on the ECtHR, was that 'foreign' judges should not interfere (too much) with local choices. ${ }^{100}$

The aspect of 'local diversity' distinguishes a federal state like the United States from the international framework of the Council of Europe. Obviously, this is not to say that there are no differences between the states in the United States, but in terms of language, religion, culture, politics, media and so on, the differences between the Member States of the Council of Europe are important. This is

98 See also D. Tsarapatsanis, 'The Margin of Appreciation as an Underenforcement Doctrine', in P. Agha (Ed.), Human Rights between Law and Politics. The Margin of Appreciation in Post-National, Oxford, Hart Publishing, 2017, p. 84 et seq.

99 See the quote from Handyside, supra note 47.

100 For instance for the Netherlands, see J. Gerards, 'The Netherlands: Political Dynamics, Institutional Robustness', in P. Popelier, S. Lambrecht \& K. Lemmens (Eds.), Criticism of the European Court of Human Rights. Shifting the Convention System: Counter-Dynamics at the National and EU Level, Cambridge, Intersentia, 2016, p. 328-329 and the numerous references. 
why in so many 'sensitive issues' the Court has to acknowledge that there is no European consensus. In times like ours, where the idea of 'taking back control' and neo-sovereignism have conquered the hearts and minds of many European citizens, the use of the margin of appreciation is a way for the Court to value local diversity. ${ }^{101}$

Now, if this holds true and if Mark Tushnet's analysis of the Footnote 4 case law is correct, then we are facing an interesting paradox. The levels of scrutiny case law would have led, in the United States, to a generalized preference for individual rights to the detriment of the 'common good'. Although I am not saying that a similar trend cannot be underscored in Europe - in fact, the dynamic interpretation of Article 8 of the Convention contributed considerably to the increased protection of individual autonomy - the margin of appreciation cannot be blamed for that. Quite the contrary. In fact, whenever the Court accepts that States can act within the boundaries of the margin on appreciation, the outcome of the case is that the interference complained of will not be found to be in violation of the Convention. So the use of the margin of appreciation, that is insofar as it demarcates a zone in which domestic authorities are free to adopt policies, is a way to bring in public good considerations in the debate on human rights.

At this point I am not turning a blind eye to the risk of majoritarianism ${ }^{102}$ or even the danger highlighted by De Meyer that States would be entitled to do anything they like as long as the Court does not consider a violation of human rights. However, it is clear that a coherent theory about the margin of appreciation can contribute to finding a fair balance between the protection of human rights and the protection of public interests. This would be completely in line with the general philosophy of the ECHR, which clearly takes into account the fact that citizens live in 'a democratic society'. ${ }^{103}$ As McCrea notes, the European model of society is 'liberal' not 'libertarian.' ${ }^{104}$

\section{Conclusion}

Judicial review will always raise questions in terms of deference. Both in the United States and in the ECHR system ways have been found to deter judges from going too far into the sphere of the 'elected branches of government'. In the European context, the specific position of the ECtHR as an international court, whose power is vested in it by an international treaty - which in itself confers upon the States the primary duty to respect human rights - adds additional elements to the deference debate.

101 K. Lemmens, 'Criticising the European Court of Human Rights or Misunderstanding the Dynamics of Human Rights Protection?', in P. Popelier, S. Lambrecht \& K. Lemmens (Eds.), Criticism of the European Court of Human Rights. Shifting the Convention System: Counter-Dynamics at the National and EU Level, Cambridge, Intersentia, 2016, p. 24.

102 Indicated by Judges Spano and Karakaş in their concurring opinion (para. 7) referred to (note 73).

103 Term that is explicitly mentioned in the second paragraphs of Arts. 8-11 ECHR.

104 R. McCrea, 'The Ban on the Veil and European Law', Human Rights Law Review, Vol. 13, 2013, p. 86. 
Levels of scrutiny doctrine and margin of appreciation are ways to implement judicial deference. However, there are important differences between the two concepts. The levels of scrutiny, however contested it may be, is a fairly strict doctrine, leading to rather predictable outcomes. ${ }^{105}$ The underpinning idea, even if practice may be more complex, is that cases fall into categories and that subsequently they are subject to the scrutiny that comes with the given category (rational basis, intermediate or strict scrutiny).

The margin of appreciation, in turn, is a much more fluid doctrine, determined by so many factors that it becomes very difficult to decide when exactly the Court will use it and, more precisely, to what kind of review it will lead. In very broad terms, it could be said that the margin of appreciation is the device that allows the Court to let States pursue public interests, albeit under European supervision.

This could be framed in particular negative terms, as a way of preferring the State's interests over individual rights. However, from a more positive perspective, it could be argued that the margin of appreciation has the potential to contribute to finding a social balance, thereby avoiding the interpretation and use of human rights in such a way that the common good or the social fabric is seriously endangered owing to an all too solipsistic interpretation of human rights. 